\title{
Spiritualita v nových sociálních hnutích: Prípadová studie neziskové organizace Embercombe
}

\author{
Spirituality in New Social Movements: A Case Study \\ of the Embercombe Non-Governmental Organization \\ Jana Obrovská
}

\begin{abstract}
In contrast with many sociological theories which presuppose the privatized and socially insignificant character of individualized and de-institutionalized forms of spirituality, this article explains the de-privatized character of alternative spirituality amongst employees and volunteers in a non-governmental organization called Embercombe (UK). Embercombe facilitates both spiritual development courses and environmental and social programmes. The organization is conceptualized as part of a new social movement, a new religious movement (New Age) and the holistic milieu. I spent three months conducting participant and non-participant observation, in-depth interviews, and document analysis to explain the ways actors interconnect their own spiritual development with an effort to transform the community and wider society. I conceptualize alternative spirituality as a cultural resource for grasping social and environmental problems which transcend the private lives of individuals rooted in the culture of Embercombe and engaged in the activities of new social movements. This article is a contribution to the study of spirituality in the public sphere (primarily in civil society) and its relationship to social change.
\end{abstract}

KEY WORDS Alternative spirituality, privatization of religion, deprivatization of spirituality, new social movements, new religious movements

\section{Úvod}

V pozdně moderních západních společnostech narážíme na spiritualitu v mnoha nejrůznějších, někdy i protikladných souvislostech. Žena na reklamním panelu v meditační pozici vyzývá k zakoupení produktu, který ji „zharmonizoval a zvýšil její pohodu“. Lékaři doporučují cvičení jógy jako prevenci proti bolení zad. Čajovny s duchovní literaturou mají svou stálou klientelu. Diskurzy o spiritualitě mohou formovat vize lepší společnosti, zaměřovat jednání člověka ke změně, podporovat ho v přjímání nových hodnot a jejich začleňování do alternativních životních stylů. Tyto výzvy a „,volání“ naplňuje spiritualita nejhmatatelněji tam, kde nová sociální hnutíl tematizují společenské problémy. Takovéhle ,aktivistické“ spiritualitě je ovšem na poli sociologie věnována jen velmi malá pozornost.

Sociální studia. Katedra sociologie FSS MU, 1/2014. S. 131-150. ISSN 1214-813X.

1 Nová sociální hnutí jsou formy kolektivního jednání organizované prostřednictvím neformálních a decentralizovaných sítí nacházejících se v občanské společnosti, jejichž cílem je redefinice 
Autoři některých sociologických teorií náboženství chápou soudobé de-institucionalizované a individualizované formy religiozity² jako privatizované (Luckmann 1967; Bruce 2002). Kladou-li si vůbec otázku po jejich sociálním vlivu, potom na ni odpovídají záporně: alternativní spiritualita ${ }^{3}$ nemá v jejich perspektivě sociální dopad mimo individuální život praktikujících. Je však oprávněné vykázat alternativní spiritualitu, pro kterou je příznačné propojování všech oblastí života jedince, do nějaké oddělené, soukromé sféry jeho bytí? Jsou autoři, kteří o tom pochybují a všímají si aktérů usilujících o společenskou změnu prostřednictvím spirituálních praktik (Beckford 2003; Lichterman 1996).

V tomto textu zaměřuji pozornost na sociální dopady praktikované alternativní spirituality. Zajímá mne především to, jak se může vztahovat k problémům, které sahají za hranice soukromého života jedince, jak je může tematizovat a usilovat o jejich řešení. Uvažuji o spiritualitě jako o symbolickém systému, který může podněcovat zájem o uspořádání různých kolektivit i celé společnosti. Budu se tedy zabývat způsoby, kterými může být spiritualita využita jako zdroj pro myšlení a jednání, které jsou v rámci činnosti nových sociálních hnutí orientovány na změnu.

Využila jsem předností strategie př́ipadové studie ${ }^{4}$ při výzkumu britské neziskové organizace Embercombe, která je dějištěm zhruba desítky různě zaměřených kurzů (spirituální programy, sociální a ekologické projekty), jež na toto místo přivádí jednotlivce i skupiny (studenty, učitele, klienty dětských domovů, firmy). Hlavním cílem výzkumu bylo určit způsoby, kterými alternativní spiritualita ovlivňuje činnost této organizace a podněcuje př́tomné aktéry k myšlení, jednání a konstruování identit vztahujících se k sociální změně. Hledala jsem odpověd' na otázku: Jakými způsoby dochází v organizaci Embercombe k procesu propojování vnitřní spirituální změny jedince s proměnou komunity a širší společnosti? Snahy

kultury a životních stylů prostřednictvím symbolického jednání a „kulturní práce“ na proměně významů a představ (podle Luke Martell in Barša a Císař 2004).

2 Religiozitu chápu jako souhrnný výraz pojímající jak institucionalizované formy náboženství (zejm. církevní), spiritualitu jedinců identifikujících se s některou ze zavedených církví, tak deinstitucionalizovanou spiritualitu, nacházející se mimo církevně institucionalizovaný prostor (např́íklad nová náboženská hnutí). Někteří autoři, na něž se odkazuji v průběhu textu (např. Beyer, Casanova, Luckmann), používají ekvivalentně pojem „náboženství“.

3 Výraz alternativní spiritualita odkazuje k potřebě odlišení spirituality př́tomné v prostoru tzv. oficiálního náboženství se zavedenou doktrínou a institucionální kontrolou od spirituality vyskytující se v alternativně institucionalizovaných a neoficiálních kontextech a postrádající jak tradicí legitimizovanou doktrínu, tak kodifikované způsoby sociální kontroly (McGuire 2002). Alternativní spiritualitou míním ne-církevní, individualizované a alternativně institucionalizované formy religiozity.

4 Př́ípadová studie umožňuje demonstrovat určitý fenomén na základě studia konkrétního př́ípadu (tzv. instrumentální prŕípadová studie, viz Stake 2006). K jejím přednostem patří možnost kombinování více zdrojů informací (dokumenty samotné organizace, jako jsou administrativní dokumenty, obsah internetových stránek, materiály uživané v jednotlivých programech) i technik sběru dat (zúčastněné pozorování, hloubkové rozhovory a studium dokumentů). Organizaci Embercombe jsem určila jako předmět svého výzkumu formou cíleného teoretického výběru. Rozlišila jsem tř̆ typy jednotek analýzy: kulturu této organizace (vize, cíle, směřování), její zaměstnance a dobrovolníky. 
o vnitřní změnu či objevování autentického Já spirituálních aktérů zde nahlížím jako významotvorné strategie, které se promítají do ustavování identity a světového názoru jedince a které mohou mít sociálně aktivistické dopady. Obrat k niternosti, který je v řadě sociologických perspektiv interpretován coby výraz individualizace ústící v odcizení (viz Lasch 1979; Lipovetsky 2008), zde nahlížím jako symbolický rámec motivující jedince k de-individualizovaným praktikám.

Ústřední problém textu formuluji s ohledem na své zaměření na spiritualitu, která se může vyskytovat $\mathrm{v}$ různých ne-privátních společenských prostorech (například vzdělávání, zdravotnictví, občanská společnost). Text koncipuji jako př́ispěvek, který zviditelňuje a pomáhá zaplnit „bílé místo“ na mapě sociologie náboženství, jež se konstituovalo vinou její dlouhodobé orientace na institucionalizované podoby náboženství ve veřejném prostoru. Fenomén de-institucionalizované a de-privatizované spirituality klade nové otázky, které problematizují dominantní interpretaci sociálního významu de-institucionalizovaných forem religiozity. Studovaný př́ípad doplňuje teorie privatizace a marginalizace náboženství v rámci sekularizačního paradigmatu tím, že představuje neočekávaná spojení: totiž spojení touhy po vnitřní proměně s vnější sociální změnou v podmínkách veřejné neziskové organizace.

\section{Jak chápat spiritualitu a kde ji hledat: Embercombe $v$ geografii holistického milieu}

Rozpoznání spirituální povahy určitého jednání a praktik je sociologickým problémem, který si vyžaduje samostatnou pozornost. Vystupuje především ve vztahu k definici ohraničující povahu jevů, které jejím prostřednictvím zachytíme, nebo které naopak uniknou naší pozornosti. Př́tomnost alternativní spirituality v organizaci Embercombe jsem nejprve odvozovala z analýzy obsahu internetových stránek: i přes ojedinělý výskyt samotného výrazu „spirituálni'“ byly texty prostoupeny specifickými pojmy a formulacemi, které se objevují jako součást výkladu alternativní spirituality v různých teoretických př́istupech (viz Hanegraaff 1999; Hunt 2003). Spiritualitu můžeme chápat jako symbolický významový systém, který odkazuje ke světu každodenního života a současně i ke světu, který je zakoušen jako každodenní svět přesahující. Spirituální praktiky jsou charakteristické záměrnou ,individuální manipulací se symbolickými systémy“ (Hanegraaff 2005: 42), a to i když se odehrávají ve skupině, a cílem rozvoje, který se vztahuje k jedinci i k definovanému celku (př́roda, společnost, vesmír). Pro spiritualitu je proto typické pozitivní hodnocení praktik, které pomáhají udržovat kontakt mezi „každodenním světem a obecnějším meta-empirickým významovým rámcem“ (Hanegraaff 1999: 372). Tento rámec (například proudění vesmírné energie) slouží k interpretování různých skutečností, sahajících od hřejivosti paprsku slunce, přes rodinné vztahy, po rozvoj globálního vědomí. Ty tak získávají spirituální rozměr.

Společně s Heelasem (2006) jsem předpokládala, že spirituální praktiky mohou vést jedince $\mathrm{k}$ prožitkům vyvolávajícím změnu jejich sebepojímání. $\mathrm{V}$ rámci těchto praktik jde o „dosahování sebe-porozumění a změny prostřednictvím hledání, prožívání a vyjadřování zdroje smyslu, který se nachází v běhu samotného života“ (Heelas a Woodhead 2005: 31). Podle McGuire (2008: 98) jde o praktiky, skrze které jedinci vtělují subjektivně smysluplné interpretace spojení mezi materiálními a spirituálními aspekty života do každodenního 
jednání. Taková spojení se mohou manifestovat v rámci zahradničení stejně jako „meditativního vaření".

Na poli sociologie náboženství je možné literaturu charakterizující soudobé formy spirituality schematicky rozdělit do dvou kategorí. V první z nich je spiritualita zkoumána v kontextu sekularizačního paradigmatu, $\mathrm{v}$ druhém případě se jedná o paradigma transformační. Autoři teorií spadajících do sekularizačního paradigmatu zpravidla předpokládají podmíněnost vztahu mezi institucionalizovanou povahou religiozity a jejím sociálním vlivem, a zároveň tak spojují individualizovanou spiritualitu se sociální bezvýznamností (viz Bruce 2002). ${ }^{6} \mathrm{Z}$ hlediska tohoto textu je stěžejní, že většina teorií sekularizace nezahrnuje definice a modely, které by pomáhaly zkoumání alternativně institucionalizovaných forem spirituality, zatímco teorie spadající do paradigmatu transformace jim zpravidla věnují větší pozornost. Tento rozdíl nabývá na významu v souvislosti s mou snahou o uchopení ne-privatizovaných a sociálních aspektů alternativní spirituality.

Předním autorem pohybujícím se $\mathrm{v}$ diskurzu transformace náboženství a vymezujícím svůj př́stup vzhledem $\mathrm{k}$ sekularizační tezi, předpokládající klesající význam religiozity v pozdně moderních společnostech, je britský sociolog Paul Heelas, který se dlouhodobě zabývá New Age spiritualitou. Podle Heelase (1996) spojuje př́slušníky New Age zaměření na Já a vnitřní život a snaha o transformaci. Změna má probíhat na úrovni jedince tak, aby žil v souladu se svým opravdovým, tj. spirituálním, já, stejně jako v rámci širší společnosti. Potřeba transformace vyplývá z přesvědčení o existenci krize (ekologické, morální), která je zapříčiněna dualistickým a redukcionistickým způsobem myšlení a $\mathrm{k}$ jejímuž překonání je třeba nabýt nového vědomí, jež se zakládá na viŕre v existenci spirituální reality (Heelas 1996). Stoupenec New Age spirituality je tak socializován do kultury, která se snaží kultivovat jeho „nové vědomí“, jehož prostřednictvím dochází ke konstruování vazby mezi jeho osobními problémy a problémy celospolečenskými.

Předpokladem osobního zplnomocnění stoupence New Age ke změně je specifické pojetí autority, které se promítlo do vymezení spirituality v kendalském výzkumu (Lancaster

$5 \quad \mathrm{Na}$ instituci založená existence a reprodukce náboženství je jeho historicky převažující formou (v západních společnostech je to především církevní model křest’anství). S procesem de-institucionalizace náboženství (viz Willaime 1998; Hervieu-Léger 1998) spojuji možnost alternativního způsobu institucionalizace spirituality (např́ílad v různých skupinách a hnutích, ale i v sekulárních a veřejných institucích). Instituci chápu jako kulturně definovaný soubor interakcí, které jsou situačně vyžadovány. Míra institucionalizace spirituality je spojena s množstvím jevů, jejichž prostřednictvím se konkrétní standardy a hodnotové orientace projevují v životě praktikantů (Fárek 2008).

6 Bruce předpokládá klesající význam náboženství pro společenský život projevující se úpadkem jeho organizací i představitelů. Podle Bruce většina jedinců praktikujících New Age spiritualitu, která je typem AS, usiluje o individuální změnu daleko více než o změnu společenskou. „Stoupenci New Age silně kritizují mnohé aspekty moderního světa, ale nedělají vůbec nic nebo jen velmi málo pro to, aby něco změnili [...]““ (Bruce 2002: 97). 
University 2003). ${ }^{7}$ Heelas a Woodhead se svými spolupracovníky v něm potvrdili tezi o spirituální revoluci.

Formy posvátna life-as zdůrazňující transcendentní zdroj významu a autority, s nímž musí být jedinci v souladu na úkor kultivování svých jedinečných subjektivních životů, budou pravděpodobně klesat. Formy posvátna subjective-life, které zdůrazňují vnitřní zdroje významu a autority a kultivování nebo sakralizaci jedinečných subjektivních životů, budou pravděpodobně růst. (Heelas a Woodhead 2005: 6)

Toto vymezení v sobě zahrnuje definiční rozdíl mezi náboženstvím a spiritualitou: předkládá obraz náboženství, které umožňuje transcendovat pozemský život a které učí jedince, jaký by měl být jeho vztah k Bohu nacházejícímu se mimo tento svět. Spiritualita naopak orientuje jedince k sakralizaci tohoto světa a sebe samotného. Posvátný je samotný život, s jeho potencialitami, vlastnostmi, kapacitami. Spiritualita se manifestuje holisticky, chápeme-li holismus s Hanegraaffem (1998: 119) jako „hledání celistvosti na všech úrovních existence“. Holistická spiritualizace života se v kendalském výzkumu promítla i do odpovědí většiny praktikujících, kteří spiritualitu považovali za určitého „ducha či životní sílu, která prostupuje vším živým“" (Heelas a Woodhead 2005: 25).

Je důležité reflektovat, kde přesně autoři hledali, a tedy i nacházeli spiritualitu. Při testování teze o spirituální revoluci se zaměřili na těžiště či pomyslná „,srdce“ (heartland) náboženského a spirituálního života ve městě Kendal. V těchto místech se odehrávaly skupinové aktivity, jejichž účelem bylo „viditelné“ navázání vztahu se spiritualitou. Zatímco těžištěm náboženství byla kongregační sféra sestávající především z církví, v př́ípadě spirituality se jednalo o holistické milieu (srov. kultické milieu [Partridge 2004]), jehož strukturu tvořily holistické praktiky a terapie (jóga, reflexologie apod.) spojené př́tomností holistického praktikanta. ${ }^{8}$ Ze zorného úhlu tohoto ve zkoumání alternativní spirituality důležitého projektu vypadly aktivity zahrnuté do činnosti veřejných institucí, jakými jsou školy či firmy (jestli terapie založená na Alexandrově technice probíhala doma u klienta nebo ve veřejné nemocnici, nebyl pro autory důležitý rozdíl), ale také některých institucí spadajících do sekundární sféry, ${ }^{9}$ jako je právě i organizace Embercombe.

7 V tomto textu věnuji velký prostor metodologii kendalského projektu, protože ta je využitelná ve výzkumu organizace Embercombe, která je městu Kendal blízko jak fyzicky, tak i charakterem praktikované spirituality.

$8 \quad$ Heelas a Woodhead (2005: 24, 27) rozlišují holistické praktikanty, kteří vedou asociativní spirituální praktiky, a participanty, kteří se jich účastní. Praktiky mohou nabývat formy setkání praktikanta s klientem nebo skupinových setkání.

$9 \quad \mathrm{~V}$ tomto textu pracuji s modelem veřejné sféry pozdně moderních společností zakládajícím se na odlišení systému politicko-administrativního (státního), sféry trhu (ekonomického) a tzv. třetího sektoru (občanského). Dále rozlišuji kategorii primárních institucí zahrnujících instituce státní (politické, vzdělávací, zdravotnické apod.), jež se vyznačují zřetelnými požadavky sociální konformity. Sekundární instituce se nacházejí někde mezi privátní a veřejnou sférou. Je pro ně typická určitá míra formálních pravidel, poskytují ale daleko větší prostor pro zkušenosti lidí, vyjadřování jejich pocitů a osobní růst (Heelas 2006). Jejich povaha i pozice mezi zcela neinstitucionalizovaným privátním prostorem a institucionální strukturou primárních institucí (typu life-as) 
Fakt, že aktivity holistického milieu nebyly v Kendalu zkoumány ve své návaznosti na širší institucionální kontext, je reflektován Heelasem (2008) v jeho pozdější práci, v níž deklaruje, že je třeba sledovat holistické aktivity vedené spirituálními praktikanty odehrávající se kdekoliv v širší perspektivě. Možnosti komparace holistického a kongregačního prostoru v Kendalu bylo obětováno sledování sociálního vlivu spirituálních praktik přítomných v institucích primární či sekundární sféry, jakými jsou holistické lázně, speciální třídy v rámci mainstreamových škol či nová sociální hnutí. Z hlediska naplnění cíle této stati je žádoucí rozšíření výchozí teoretické perspektivy, protože ta vtiskuje tvar výzkumnému poli, v němž se budeme pohybovat. $Z$ teorie vycházející metoda nás může opakovaně vést ke hledání spirituality jen v některých kontextech, které potvrzují předpoklad o jejím zanedbatelném sociálním vlivu a významu.

\section{Od holistického milieu k holistickému hnutí}

Když autoři kendalského výzkumu lokalizovali studované jevy, zjistili, že při zkoumání holistického milieu budou muset vykročit za hranice původně jasně ohraničeného prostoru města Kendal, protože tam nalezli dvě významná holistická centra (Heelas a Woodhead 2005). Pro analýzu alternativní spirituality v rámci nových sociálních hnutí je tato skutečnost důležitým momentem. Spirituální centra se sice často nacházejí na venkově či v divoké přírodě, ale mají vazby na dění v okolních i vzdálenějších městech a v institucích mainstreamové společnosti.

Počátky mého pobytu v Embercombe byly provázeny jistou dezorientací kvůli rozmanitosti skupin lidí, které na místo přicházely, i vazeb, které organizace udržovala s okolními organizacemi a platformami. Organizace spolupracuje se základními školami, firmami, státními univerzitami, ale i s alternativně zaměřenými univerzitami soukromými. Jednou z nich je i celosvětově významné centrum v sítích alternativní spirituality, Schumacher College. ${ }^{10}$ Corrywright (2004) navrhuje zkoumání formálních i neformálních spojení osob, míst, periodik a organizací v násobících se sítích zkoumaného prostoru. Dynamika této otevřené struktury umožňuje začlenění nových uzlů za předpokladu sdílení určitých symbolických kódů. Ačkoliv mnozí autoři problematizují pojímání New Age jakožto „hnutí‘11 (Ondrašinová 2010: 121-126), přítomnost sdílených symbolických kódů podněcujících vzájemnou komunikaci a umožňujících formulaci cílů aktivit mezi různými asociacemi považuji spolu s Meluccim (1996) za důležitý znak hnutí.

modelově vyjadřuje typickou spirituální praktiku holistického milieu, stejně jako aktivity nových náboženských a nových sociálních hnutí.

10 Univerzita je pojmenována podle E. F. Schumachera, který je významnou postavou New Age holistického paradigmatu propojujícího ekologii a ekonomiku s konceptem udržitelnosti.

11 Hnutí chápu jako: „Skupinu lidí, která je organizovaná, ideologicky motivovaná a odhodlaná k naplnění cíle, který uskutečňuje nějakou formu osobní či sociální změny, která aktivně získává další stoupence a jejíž vliv se šíři v opozici k ustavenému sociálnímu řádu, v rámci kterého se zformovala" (York 1995: 325). 
V souvislosti se sít'ovou povahou nových náboženských hnutí12 kritizuje York (1995) tendenci mnoha autorů chápat nízkou úroveň jejich formální organizace jako její absenci. Při analýze na změnu orientovaných hnutí, která nezahrnují jen hnutí náboženská (např. New Age), ale také hnutí sociální (feministická, environmentální), navrhuje York aplikaci konceptu SPIN (Segmented Polycentric Integrated Network). Jde o rozsáhlou, decentralizovanou organizaci, v níž jsou hierarchie a závazky vtělené do jednotné doktríny nahrazeny dobrovolnou spoluprací částečně autonomních aktérů (York 1995: 330-331). York dále tuto perspektivu rozšiřuje a načrtává obrysy holistického hnutí, když mluví o siti všech sítí (SPIN of SPIN), která umožňuje souběžnou analýzu hnutí New Age či feministické spirituality.

Geografii spirituálního hnutí zachycuje také Forman (2004), který mapoval kořeny spirituálního hnutí (grassroots spirituality movement) v americké společnosti. Autor identifikoval desítky spirituálních směrů a tradic, které chápe jako dialekty jednoho společného jazyka. Ačkoliv se toto hnutí vyvinulo neorganizovaně, postrádá vedení a jeho hranice jsou silně prostupné, dle Formana sdílí jeho prŕslušníci určitý pohled na svět (worldview), který může být komunikován a je v něm tak přítomen potenciál sjednocení a společné akce. Analogickým konceptem je progresivně spirituální milieu britského sociologa Lynche (2007), které reprezentují teologicky liberální či zeleně a levicově politicky orientovaní jedinci, skupiny a sítě. Milieu sdílí určitou ideologii a je základem pro produkci spirituálních identit, podporu vzájemné komunikace a šíření politického či sociálního aktivismu.

Organizace Embercombe je segmentem v síti holistického hnutí, které zahrnuje jak nová náboženská, tak nová sociální hnutí. Organizaci chápu jako součást environmentálního hnutí i hnutí New Age.

\section{Privatizace náboženství}

Abychom mohli důkladně analyzovat vztah mezi alternativní spiritualitou a novými sociálními hnutími, je třeba zmínit některé sociologické debaty diskutující pozici a funkci náboŽenství v moderních společnostech. Ve 20. století se jako nejrozššřrenější způsob, jak vysvětlit vztah vývoje náboženství a modernity, ukázala být sekularizační teze (secularization thesis). Podle ní vede proces sekularizace k emancipaci sekulárních sfér od sféry náboženské, ke kvantitativnímu poklesu míry náboženského praktikování a k marginalizaci společenské pozice, v níž se náboženství nachází. Nebývalá shoda ohledně výsledku tohoto procesu je důvodem, proč někteří autoři začali teoriím sekularizace připisovat paradigmatický status (Casanova 1994; Hadden 1987; Tschannen 1991).

Jedním z klíčových sdílených paradigmatických prvků těchto teorií je teze o strukturní diferenciaci, tedy o postupném vydělování funkčně specializovaných, autonomně fungujících sfér, jehož součástí je ustavování vlastní náboženské sféry. Jednotlivé subsystémy mají vlastní specializovaný jazyk a pravidla, spojuje je funkční orientace a dominantní forma

12 Hnutí New Age, které v této práci pojímám jako alternativně spirituální, bývá řazeno do kategorie nových náboženských hnutí (Lužný 1997). Ačkoliv v této práci reflektuji rozdíl mezi spiritualitou a náboženstvím, zároveň pracuji s ne zcela přesným, nicméně zavedeným označením „nová náboženská hnutí“. 
zdůvodňování, jíž je instrumentální racionalita. Casanova (1994: 17) chápe teorie sekularizace jako sub-typ obecnějších teorií modernizace a diferenciace a poukazuje na osvícenský normativně-ideologický základ některých z nich, jehož výsledkem je spojování diferenciačních procesů s očekávaným zánikem náboženství. Herbert (2003) kritizuje teorie sekularizace, protože strukturní diferenciaci vykládají jako samozrejmý proces s neutrálními důsledky, přičemž jedním z nich je snižující se sociální vliv náboženství. Podle něj jsou procesy diferenciace doprovázeny de-diferenciačními tendencemi (naprŕíklad kolonizace sociálního subsystému subsystémem ekonomickým), jejichž důsledky nemusí být vždy neutrální (např́klad v prrípadě ekologických problémů).

Podle Thomase Luckmanna vzniká souběžně s postupujícím procesem institucionální diferenciace prostor označovaný jako soukromá sféra, do níž umist’uje i nově se objevivší sociální formu de-institucionalizovaného náboženství. V této sféře, která poskytuje modernímu individuu ,iluzorní představu autonomie“ (Luckmann 1967: 97), vznikají privátní náboženské reprezentace charakteristické sakralizací individuální identity, k nimž jedinec zaujímá konzumní vztah. Autor sice nepředpokládá ani tak pokles náboženství v moderních společnostech, jako spíše změnu jeho pozice, poukazuje ale na jeho nezvratitelnou strukturní a kulturní privatizaci. Podobně jako Bruce (2007), z jehož pera a často v polemice s Heelasem (2007) zaznívá argument o prchavosti a sociální bezvýznamnosti alternativní spirituality, akcentuje i Luckmann nestálost individuálně a privátně konstruovaných náboženských systémů. ,, ,Autonomní konzument si vybírá určitá náboženská témata z dostupné nabídky a vytváŕí křehký privátní systém nejvyšší důležitosti““ (Luckmann 1967: 102). Tato témata (seberealizace, sexualita) jsou sociálně zprostředkovávána v kultickém komercionalizovaném prostředí. „Převažující formu systému nejvyšší důležitosti tvoří nestabilní hierarchie významů legitimizující emočně utvořené priority jedince v jeho privátním životě“ (Luckmann 1967: 105). Proces privatizace náboženství tak optikou Luckmannova př́istupu vede k subjektivizaci náboženských reprezentací, které jako takové nemohou tvořit jednotný výklad světa, a k depolitizaci náboženských institucí (Casanova 1994: 35).

Luckmannem (1990) analyzovaná souvislost mezi strukturální privatizací veřejného života a sakralizací moderní subjektivity rezonuje s řadou dalších sociologických teorií. Představa autonomie se tu snoubí se zbožšt’ováním individuální hodnoty jedince a paradoxně ústí v nereflektované posvěcení autonomie primárních institucí. V souvislosti s narcistickým únikem do soukromí Lipovetsky (2008: 86) píše:

Psychoterapie, případně zabarvená tělesným cvičením či orientální fillosofií, vede člověka, aby se zabýval pouze vlastním Já, které je tak povýšeno na pupek světa. [...] Narcis posedlý sám sebou nezahálí, nedřímá a nesní, nýbrž usilovně pracuje na osvobození svého Já, na dosažení autonomie a nezávislosti.

Jednou z linií této statě je polemika se sociologicky převažujícím obrazem individualizovaných spiritualit, který je vykresluje coby sebe-pohlcující (Bruce 2002), narcistní (Lasch 1979) praktiky usilující o zvýšení efektivity a vizuálních, motivačních a výkonostních kapacit těl ve strukturách pozdního kapitalismu (Bishop 2008). Řada forem spirituality př́tomných na spirituálním trhu má bezpochyby solipsistický charakter (viz v Česku velmi rozšířené esoterické klientské služby) a řečeno s Laschem (1979) může ústit v odosobnění či neschopnost 
navazovat trvalejší sociální vazby. Zaměřuji se na ty formy spirituality, jejichž prostřednictvím dochází ke konstruování vazby mezi vnějším a vnitřním rozvojem jedince a sociální akcí. Vrat'me se k Luckmannovi, kterého chápu jako předního reprezentanta teorií privatizace a subjektivizace $\mathrm{v}$ oblasti sociologie náboženství. Jeho analýza je $\mathrm{z}$ hlediska této práce důležitá, protože neztotožňuje religiozitu s její církevně institucionalizovanou formou, a je proto aplikovatelná i na fenomén alternativní spirituality. Chceme-li se zabývat sociálním významem a vlivem alternativní spirituality se zaměřením na její vazbu k novým sociálním hnutím, musíme se ovšem k tezi o privatizaci a Luckmannově konceptualizaci „neviditelného“ náboženství1 ${ }^{13}$, která výrazně ovlivnila transformační paradigma, vztahovat kriticky. Jak upozorňuje Besecke (2002), na Luckmannovu teorii navazoval v sociologii náboženství skoro každý, aniž by ji kdokoliv podrobil systematičtější kritice. Aupers s Houtmanem (2006) polemizují s privatizační tezí především $\mathrm{s}$ ohledem na pozorovatelnou expanzi alternativní spirituality ze sekundárních do primárních institucí, stejně jako z hlediska vlivu prožívání vnitřní spirituality na rozhodování a volby potřebné pro každodenní život jedince ve veřejném, „vnějším“ světě.

\section{Propojování soukromého s veřejným: Kontury deprivatizované spirituality}

Casanova vybízí ke sledování míry, v níž jsou teorie předpokládající privatizaci náboženství zakotveny v normativních základech liberálního modelu veřejné sféry. Podobně jako Heelas rozpracovává sekularizační tezi způsobem, který umožňuje zachytit změněnou povahu náboženství v moderním světě a nepředpokládá jeho zánik. Na rozdíl od Heelase a v rozporu s povahou této práce se zaměřuje spíše na tradiční institucionalizovaná náboženství typu life-as. Partridge (2004: 124) Casanovu doplňuje a připisuje potenciál $\mathrm{k}$ deprivatizaci i alternativní spiritualitě. Teorie sekularizace Casanova kritizuje z hlediska nezvratitelného pojetí jimi zachycovaných trendů vývoje náboženství, které z nich činí namísto „deskriptivních normativně-preskriptivní teorie moderních společností, které ideologicky legitimizují určitou historickou formu institucionalizace modernity“ (Casanova 1994: 41), a předkládá komplexněǰśí obraz pozic, rolí a funkcí, které může náboženství v moderní společnosti plnit a zaujímat. Dominantní výklad vývoje náboženství v moderních společnostech doplňuje o proces deprivatizace. Náboženství získává možnost ke vstupu do veřejného prostoru: pokud brání právo existence občanské společnosti proti absolutistickému státu; pokud problematizuje absolutní autonomii sekulárních sfér a jejich fungování podle strukturně diferenciačních principů bez ohledu na etická dilemata tohoto fungování; nebo pokud vstupuje do veřejného prostoru, aby chránilo tradiční žitý svět před jeho ohrožením ze strany státních zásahů (Casanova 1994: 57-58).

Popsané problematizování autonomního fungování jednotlivých sfér deprivatizovaným náboženstvím je možným způsobem vysvětlení situace, kdy se alternativní spiritualita stává kulturním zdrojem pro kritiku environmentálních, sociálních či globálních problémů, a tím rovněž zdrojem pro konstruování nových hranic mezi těmito sférami. $\mathrm{V}$ př́ípadě spirituálně motivovaných aktivit se jedná spiše o vstupování do procesu diskurzivního vyjednávání

13 Jako paradigmatický př́klad neviditelného náboženství, jehož „neviditelnost“ spočívá ve slabé institucionalizaci, přímé dostupnosti a komercionalizaci, slouží Luckmannovi (1990: 136-137) New Age. 
významů, hranic a definic, jež se odehrává více v rovině symbolické a kulturní, než formou př́mého zapojování do procesů politického rozhodování. Tyto aktivity na sebe často berou podobu kritiky funkcionálně racionální logiky a nároků autonomie ekonomického a administrativního systému.

Z podobné pozice jako Casanova zachycuje možné veřejné role náboženství v současných společnostech i Herbert (2003). Teorie sekularizace kritizuje za jejich směšování vitality a sociálního vlivu náboženství. Sekularizační paradigma zdůrazňuje pokles míry praktikování (vitality) institucionalizovaného náboženství, obvykle ale nedostatečně reflektuje vliv, který má náboženství na jiné sociální systémy. Vzhledem k proměnám jeho kulturních forem chápe autor jako příznačné pojímat náboženství jako diskurz osvobozený od autoritativních institucí, který může ,způsoby náboženského myšlení a reprezentování dobývat veřejnou představivost i nabízet způsoby, jimiž jsou diskutovány problémy“ (Herbert 2003: 15). Tento model umožňuje zachytit proti-sekularizační, deprivatizační, ale i de-diferenciační sklony náboženství jako určitého významového systému. Jedním z kontextů jeho působení je rezistence proti sílícímu prostoupení sociálního života instrumentálními a funkčními imperativy.

Alternativní spiritualita může vzhledem ke své holistické povaze „smysluplně integrovat diferencované sféry“ (Knoblauch 2008: 46). Stává se tak zdrojem využitelným pro artikulování rezistence namířené proti prŕilišné autonomii jednotlivých sfér přítomné v nových sociálních hnutích.

\section{Spirituální environmentalismus: Řešení reziduálních problémů}

Ačkoliv struktury moderní společnosti podporují privatizaci náboženství, nevylučují možnost jeho veřejného vlivu. Především v kontextu činnosti současných nových náboženských a sociálních hnutí dochází $\mathrm{k}$ pokusům o prosazování kolektivní závaznosti norem a hodnot ve veřejném prostoru. V této souvislosti je třeba rozlišit funkci, tedy způsob vztahování náboženství coby samostatného sub-systému k celku společnosti, a performanci, tedy způsob jeho vztahování k ostatním sub-systémům (Beyer 1994). Funkce je čistou náboženskou komunikací (např́iklad dosažení spásy, osvícení), k performanci dochází v prrípadě, že je náboženství aplikováno na problémy utvářené jinými systémy (tj. ne-náboženskými), které ale nejsou $\mathrm{v}$ jejich rámci řešeny nebo vůbec adresovány. Těmito problémy může být rodinné odcizení, environmentální degradace nebo politický útlak. Náboženství se tak stává zdrojem, který tematizuje to, co jsou z perspektivy dominantních sociálních systémů (zejména ekonomického a administrativního) reziduální problémy, jejichž produkování není spojováno se samotným fungováním těchto systémů.

Ačkoliv alternativní spiritualita není v Beyerově perspektivě schopna zvrátit trend privatizace náboženství, je důležitým ideovým zdrojem pro nová sociální hnutí, která se zaměřují na globální mír, problematiku sociální spravedlnosti a environmentální rovnováhy. Tato hnutí umožňují ,přemostit mezeru mezi privatizovanou náboženskou funkcí a veřejně vlivnou náboženskou performancíc (Beyer 1994: 107). Tuto tendenci ilustruje především na tzv. náboženském environmentalismu, charakteristickém propojením lidského a přírodního světa, zdůrazňováním vazby mezi lokálním jednáním a stavem celého světa (Beyer 2001). 
Beyerova interpretace aktivit nových sociálních hnutí je ukazuje ve světle snah o ustavení hodnot udržitelnosti a kvality života, namísto pokroku a růstu, a smyslu existence přesahující materiální prospěch. V této situaci se alternativní spiritualita stává organizačním, ideologickým a motivačním zdrojem, prostřednictvím kterého mohou lidé konceptualizovat reziduální problémy a který je může mobilizovat k pokusům o jejich řešení. Bloch (1998) ukazuje, že v jeho výzkumu byl environmentalismus důležitou součástí alternativní spirituality. Aktivity vedoucí k ochraně Země byly interpretovány jako spirituální.

\section{Nová sociální a náboženská hnutí: Objevování zjevných paralel}

Pro vymezení role alternativní spirituality v nových sociálních hnutích je nezbytné rekapitulovat koncepce, jejichž prostřednictvím je zkoumán vztah mezi novými sociálními a náboženskými hnutími. Průzkum literatury ukázal, že jsou kapkou v moři všech ostatních sociologických teorií náboženství, jejichž autoři z různých důvodů alternativní spiritualitu jako činitele změny nepojímají.

Nedostatek př́íspěvků věnovaných novým náboženským hnutím v textech zabývajících se novými sociálními hnutími považuje Beckford (2003: 165) takřka za „perverzní“. Vybízí proto $\mathrm{k}$ jejich propojenému studiu a nachází prvky alternativní spirituality v ideologiích některých nových sociálních hnutí. Teoretiky nových sociálních hnutí dlouho spojovala nevole zařadit do kategorie kolektivního jednání náboženská hnutí, protože pro ně nepředstavovala závažnější hrozbu společenskému řádu. Náboženství v jejich perspektivě spiše „vyzývá své stoupence ke dlení v konzervativních nebesích, než že by je vedlo k aktivitám zaměřeným na transformaci okolní společnosti“ (Beckford 2003: 161). Hannigan (1991) nevoli těchto autorů chápe jako výraz sdíleného marxistického zakotvení.

Přední teoretici nových sociálních hnutí (Habermas, Touraine, Offe) odmítají posvátno chápat jako zdroj pro převzetí kolektivní zodpovědnosti za sociální změnu. Jak ale ukazuje Beckford (1989), jedním z důvodů tohoto předpokladu je ignorování výzkumů alternativní spirituality, stejně jako ztotožňování náboženství s tradičními církvemi, případně sektami. Právě v oblasti holistického milieu, respektive hnutí, bychom z perspektivy této práce mohli hledat významotvorné strategie konstruující propojení vnitřního růstu s vnější změnou.

Alberto Melucci (1996) připouští, že alternativní spiritualita může být zdrojem výzvy sociálnímu řádu. Kolektivní jednání pozdně moderní doby pojímá jakožto vyzývání dominantních kulturních kódů v podmínkách informační společnosti. Melucci je hlavním proponentem teorie nových sociálních hnutí, kterým nejde, na rozdíl od klasických hnutí moderní doby, o materiální prospěch nebo zahrnutí do politického systému, jako spíše o ustavení autonomních prostorů komunikace s důrazem položeným na odpor proti sociální kontrole ve sférách každodenního styku (Barša a Císař 2004: 103-104). Nová sociální hnutí tak věnují pozornost oblasti nekontrolovatelného a neměřitelného - tedy i spirituálního, jež byla vyřazena z činnosti sociálních hnutí působících před 60 . lety 20. století (např́íklad tradiční projekty dělnických hnutí, starší formy politiky obhajoby občanských práv apod.). Prozkoumávání této oblasti zahrnuje i „potřebu spojení vnější změny s vnitřním růstem“ (Melucci 1985: 812). Stoupenci těchto hnutí jakoby pracovali na novém způsobu pojmenovávání světa skrze 
rozvíjení jazyků a kódů, v nichž je reinterpretován symbolický vztah člověka ke světu a př́irodě a zpochybňován dominantní vědecko-technický diskurz. Podle Melucciho jsou do alternativních kódů vtělovány ty aspekty existence, které byly vykořeněny technickou racionalitou - hravost, fantazie, rovnováha mezi tělem a duší. „Pokud je možné ,předělat‘ svět tím, že přijmeme nové způsoby pojmenovávání, vnímání a představování reality, potom je možné předělat či přesázet různé části svého já“ (Melucci 1996: 358).

Právě zaměření na politiku identity je jednou $\mathrm{z}$ cest souběžného studia nových sociálních a náboženských hnutí. Ta je součástí každodenního života a implikuje nové formy významů a vědění o světě a identity, které jim př́ślušejí. $V$ tomto kontextu je důležité neopomenout afektivní, expresivní a lifestylové prvky identitotvorných procesů, protože tak činí řada teoretiků těchto hnutí, kteří akcentují především racionální a reflexivní aspekty těchto procesů (Hetherington 1998). Melucci se domnívá, že spirituální může být „apelem k možnosti jiného“, že tento typ zkušenosti zahrnuje konfliktní obsahy, protože ty se vztahují k definování významu. Konflikt probíhá na symbolické bázi, není otevřeně kritickým k sociálnímu systému, nemá striktně politickou formu. Melucci tak podobně jako Heelas předpokládá, že jedinec prostřednictvím spirituální transformace často usiluje o „obývání světa s hlubším vědomím“ (Melucci 1996: 172), jež se vyznačuje aktivní snahou o opuštění dominantní logiky reprezentace.

Problematice spirituality $\mathrm{v}$ nových sociálních hnutích věnuje pozornost také Bloch (1998), který mluví o kontrakulturně spirituálním hnutí. „Alternativní spirituální identita se vztahuje k individuálním i sociálním potřebám a diskurz, který udržuje tento typ flexibilní a přizpůsobivé sociální role, dává podnět jak k vlastní autonomii, tak ke smyslu přináležení k širšímu sociálnímu hnutí“ (Bloch 1998: 24). Takové hledání přináležení se u řady stoupenců alternativní spirituality vyznačuje symboly, jakými jsou láska $\mathrm{k}$ Zemi, spirituální rovnováha či spojení s původními kulturami.

\section{Spiritualita aktivizující: Cesta osobní proměny}

Internetové stránky organizace Embercombe, které představují vstupní bránu pro většinu z těch, kteří se dostali do blízkosti jejího světa, výrazy „spiritualita“, „duchovní“ či „víra“ nehýří. I když bližší pohled poodkryje mnohé kontexty a slovní spojení, z nichž zaznívá holistický jazyk charakteristický pro kulturu New Age (,autentičtí lidé“, „,esta sebe-objevování“, „magické místo“), většina obsahu jakoby nechávala svou spirituální dimenzi kdesi v pozadí. V každodenním životě osob podílejících se na chodu této organizace se ovšem spiritualita obnažuje: stává se předmětem rozhovorů, podněcuje jednání, má své institucionalizované projevy (Thomasovy holistické terapie se zaměstnanci hlavního týmu, ceremonie spojené s chodem organizace připomínající přechodové rituály) i více či méně spontánní neformální podoby (víkendové meditace v lese, ženský a mužský kruh). Převážná většina aktérů se věnuje spirituálním praktikám také individuálně, přičemž jejich diverzita postihuje škálu praktik př́tomných v holistickém milieu - buddhistické meditace, Chi Kung, akupunktura, šamanismus. S přibývajícím věkem jednotlivých aktérů přibývá i pomyslných zářezů v jejich spirituální biografické sbírce. 
Pojítkem různých forem spirituálních snah aktérů v Embercombe je jejich usilování o osobní i vztahovou autenticitu, skrze které jsou jedinec i společenství v souladu s transcendentní energií, přičemž tento soulad garantuje rovnováhu, zdraví a udržitelnost. Samotné pojetí autenticity často odkazovalo k existenci posvátného principu, s nímž musí být jedinec v souladu, má-li jí dosáhnout. Praktikování spirituality ve smyslu zviditelňování neviditelného či zpř́stupňování tušeného není jen doménou ranní půlhodinky meditace. Tendence vsakování spirituality do každodennosti, jejího prostupování většinou činností je odrazem způsobu, kterým si ji aktéři definují. V jejich snaze pojmenovat něco, co se jen velmi těžko vyjadřuje slovy, byly patrné stopy heelasovské sakralizace života.

Pro mě duch představuje výchozí vědomé bytí, které umožňuje existenci jako takovou. Je to životní síla, něco, co nás všechny spojuje, i když to nevidíme. Ale můžeme to cítit a poznat a já si myslím, že meditace je jednou z těch praktik, které ti umožňují cítit ducha v sobě samém. (Tim, 27. 11. 2010)

Pro Tima meditace představuje spojování se s univerzální energií, která jím protéká, a její důležitou částí je rozšiřování vědomí a procitování vnitřního míru tady a ted'. Pro Thomase je život ve své podstatě posvátný, a když se snaží vystihnout jádro své spirituality, dochází k jejímu ohraničení skrze to, čím není: spiritualita je nezasahováním do procesu bytí. Odpovídajícím způsobem vztahování se k něčemu, co je posvátné, je úcta. Prvky eko-spirituality i spirituality života mají pronikat do každého aspektu bytí, a to ještě intenzivněji tam, kde jedinec nezůstává $\mathrm{v}$ této snaze osamocen, kde jsou symbolické rámce tohoto typu vtěleny do cílů fungování celé organizace. Pokud je úcta k životu hluboce zasazena v jedinci, potom všechno, co udělá, jak předpokládá Stuart, bude pro-život, bude výrazem lásky a péče o vše živé.

Jedním z klíčových symbolických rámců silně zakořeněných v kultuře organizace Embercombe je koncept spirituální cesty, podle kterého je i pojmenován jeden z jejích nejvýznamnějších kurzů. Př́běhy individuálně proměnlivých duchovních cest spojuje důraz položený na sebe-objevování skrze experimentování a horizont, k němuž má tato explorace vést.

Snažíme se vyzvat k setkání. Jde o setkání se sebou samým a sebe-objevování jako jeho důležitá součást. Bylo by úplně špatně, kdybychom nabízeli krásné malé balíčky alternativ typu: podívej se, takhle děláme věci, takhle žijeme život, takhle je to nejlepší. (Robert, 17. 12. 2010)

V Robertově perspektivě je cesta nástrojem, který pomáhá lidem prostřednictvím osobního růstu nalézat odpovědi na palčivé otázky. Je to „umění žití života s otázkou“ (Mel, terénní poznámky, 26. 10. 2010). Předpokládá se přitom, že „skutečné“ či autentické setkání se životem je do jisté míry konfrontační a potenciálně tak přináší, řečeno s Meluccim, konfliktní obsahy. Otázky, jejichž odpovědi se nějakým zpo̊sobem vztahují ke spiritualitě, jsou: Co chci v životě dělat? Jaké jsou mé hodnoty? Co chci přinést světu? To potvrzují Aupers s Houtmanem (2006) i Peter, jeden ze dvou hlavních organizátorů kurzu Katalyzátor (Catalyst), zaměřeného na sebe-proměnu vysokoškolských studentů, který princip duchovní cesty chápe jako pohyb od „nevědomého jednání přes vědomé bytí k uvědomělému jednání“ 
(Peter, 13. 11. 2010). Jednání zaměřené na vnější svět je nedílnou součástí vnitřní cesty. Hlavním posláním programu Katalyzátor je:

Budování silné sítě mladých lidí - autentických vůdců, nositelů změny, schopných vypořádat se s výzvami tohoto světa osobitým způsobem, zatímco jejich životy budou naplněné a budou mít smysl. Naší vizí je generace jedinců podněcujících změnu, kteří přispívají celým svým srdcem $\mathrm{k}$ vizi spravedlivého a udržitelného světa. (Embercombe, nedatováno)

Peter rámuje směřování tohoto kurzu kritikou stavu univerzitního vzdělání, které nenabízí prostor pro spirituální růst. Jako bývalý student waldorfské školy v Německu přišel do Embercombe, aby si mohl zodpovědět důležité životní otázky. Ted' chce mladé lidi povzbuzovat $\mathrm{v}$ tom, aby vyšli do světa a pracovali pro to, co považují za důležité (terénní poznámky, 13. 10. 2010).

Součástí těchto procesů je často zpochybnění obecně přijímaných konvencí, připouštění vize jiného světa a role jedince v něm. Formování takové vize, jež je důležitou strategií New Age hnutí (viz Hanegraaff 2005), stejně jako mnoha hnutí sociálních, vychází v kultuře organizace $\mathrm{z}$ experimentování s povahou tzv. komfortní zóny jedince. Model komfortní zóny a strategie jejího rozšiřování byly součástí většiny kurzů, kterých jsem se zúčastnila. Úzký komfortní kruh obklopuje zóna risku. Vychází se z předpokladu, že v komfortní zóně se nemůže dít nic zvláštního, a jedinec se tak nemůže rozvíjet ani spirituálně růst. Bariérou stagnace je riskování, rozšiřování a holistické balancování intelektové, emoční, spirituální a fyzické složky. Charismatického Stuarta jsem viděla mnohokrát působivě ilustrovat duchovním hledačům, stejně jako zaměstnancům pojišt’ovací společnosti, situace, kdy se hranice komfortu boří a člověk začíná růst.

Ten, kdo je vtažen do kultury organizace, může slyšet tiché volání: Nevyhýbej se výzvám, které život přináší. Potýkej se s nimi! Kdo chce poslouchat ještě víc, slyší: Přemýšlej nad tím, jak žiješ, objev své dary a zhmotni je v praktických činech. Pro některé skupiny lidí může být toto volání sotva zachytitelné, zaměstnanců a dobrovolníků se dotýká př́mo.

Jedinec nesmí stavět překážky toku spirituální energie či ducha, a naopak by měl dělat vše proto, aby se s ní spojil. Zaměstnanci se proto ve vztahu ke svým klientům často chápou jako činitelé změny. Odstraňují překážky, léčí, prohlubují způsoby vnímání účastníka kurzu. Anna chápe kurz Cesta (Journey) jako explicitně transformační, vedoucí účastníky k takové podobě žití života, který je žití hoden. Jeho nedílnou součástí je i reflexe toho, co jedinec může předat světu. Thomas se snaží uvolnit ukotvení jedince, jeho fixxované představy o životě tak, aby mohl objevit širší perspektivu a reflektovat kontext, v němž žije. Prosazuje změnu skrze povznesení ducha a vybízí ke konfrontaci s tím, co je obtížné. V majoritní kultuře, která podle něj podporuje vyhýbání se problémům, vyzývá k přímému střetu. K překonání „uspávacích, ztracených, ignorujících, neúplných a nejasných stavư“ (Thomas, 27. 11. 2010) osobní proměnou. Podněcování a inspirování k proměně sebe sama může vést ke zvýšenému pocitu zplnomocnění jedince, protože „,tolik lidí má daleko větší představu o své bezmocnosti než o své síle“ (Stuart, 15. 11. 2010). 


\section{Spiritualita experimentující a angažovaná: Proti proudu a za Novou Zemi}

Způsobem, jak zažehnout jiskru aktéry chtěné osobní proměny i jak malovat obraz jiné budoucnosti, je podnícení představivosti. Ta se nejpř́měji kultivuje skrze snění, které nabývá v prostředí organizace na spirituálním obsahu v instituci snílka (dreamer), protože jejím prostřednictvím může být proživána spiritualita. Každý den může být někdo zbaven povinnosti pracovat a je vyzván $\mathrm{k}$ tomu, aby snil.

Lidi tu pracují hodně tvrdě a někdy tak ztrácejí rovnováhu. Protože máme tak silnou vizi, která přitahuje hodně motivované jedince. [...] proto máme určité věci, jež jsme ustavili pro udržení harmonie, jakou je třeba i snilek. (Anna, 6. 11. 2010)

Annina výpověd’ zachycuje dlouhodobou embercombskou debatu o rovnováze mezi bytím a děláním. Pokud má snění vést $\mathrm{k}$ balancování bytí a dělání, je výrazem nastavování limitů imperativům instrumentální racionality a zároveň prostředkem $\mathrm{k}$ intenzivněǰ̌ímu prožívání spirituality. Snění vedlo aktéry zpravidla ke snaze o zakoušení bytí jako takového, zpřítomnění. Zároveň k představování si takového fungování organizace, v němž převažuje autenticita a život v souladu s jeho duchovní dimenzí na úkor dělání, které reprezentuje bytí zbavené posvátnosti.

Snění otevírá nový horizont: pozorování každodenního dění v organizaci z odstupu, hlubší spojení se Zemí (například strávením celého dne o samotě v lese) a následné vtělení dojmů a prožitků do návrhů potenciálních změn ve fungování organizace i k použití snílka jako modelu aplikovatelného v každé instituci v podmínkách sekulární mainstreamové společnosti.

Spiritualita se ve výpovědích aktérů jeví jako síla propojující vše živé. Jednání vztahující se $\mathrm{k}$ propojenému celku tak má $\mathrm{v}$ jejich perspektivě spirituální povahu. Za prríčinu neutěšeného stavu současného světa je v Embercombe často považováno rozpojení (disconnection), a proto je jedním z hlavních cílů řady spirituálních praktik opětovné navázání spojení (at’ už s duchem, energií, životní silou), a to nejčastěji kultivací autentického Já či prohlubováním úcty $\mathrm{k}$ přírodě. Ta se má podle Susi rozvíjet

[R]ozpoznáním vzorů v přírodě, chápáním propojenosti všeho. Viděním celých cyklů. Jdeme trreba do zahrady, kde natrháme nějaké mrkve, a pak jdeme do kuchyně, kde se vaří, a slupky jdou na kompost a je to cyklus. Můžeme vidět jeho každou část a uvědomovat si ho. Myslím si, že to je to, co chybí životu venku. Lidi to nevnímají. (Susi, 13. 11. 2010)

Výrazy „propojený“ či „spojený“ (connected) př́ímo dominují jazyku aktérů organizace, dokumentům organizace i mým terénním poznámkám. Spiritualizovaný koncept propojení se často ve výpovědích aktérů prolíná s udržitelností, která je explicitním symbolickým jádrem, ze kterého se odvíjí veškerá činnost organizace a které je komunikováno směrem ven: do okolního světa a veřejné sféry. Převažuje snaha o udržitelnost ekologickou, mluví se ale také o udržitelném rodičovství či včelařství. To, co je spirituálně neuspokojivé (např́ílad vztah $\mathrm{k}$ Zemi, vztah rodičů $\mathrm{k}$ jejich dětem), je zde chápáno jako neudržitelné, vedoucí k různým druhům problémů. Zdůrazňování jednoty je protikladem trendů takřka ztotožnitelných s modernitou: strukturní diferenciace a specializace. 
Propojení spirituálních praktik s představami o „skutečně udržitelném světě“ implikuje ekologické hledisko, jež je v organizaci fyzicky demonstrováno na každém kroku - preferováno je organické, lokální, recyklovatelné, prosté. Rozhovory nad nápady, jak stávající životní styl učinit ještě udržitelnějším, začleňování podnětů přinesených učiteli, léčiteli, aktivisty i řemeslníky - to vše je součástí všednosti. Holismus spirituality nabízí výchozí bod pro tematizování reziduálních problémů, environmentální problémy jsou zároveň vhodnou formou pro širrení spirituálního poselství. Embercombe tak podobně jako řada nových sociálních a náboženských hnutí produkuje de-diferencovaný holistický významový horizont, díky kterému může vykonávat tzv. veřejnou performanci (Beyer 1994).

Explicitně vtělenou praktikou (McGuire 2008) je zkušenost se zasazením jedince (being planted) spočívající ve vykopání díry v zemi, symbolickém zasazení a přeměně člověka ve strom. Susi popisuje svou zkušenost s touto praktikou:

Nejprve jsem se cítila velmi klidná a jako bych byla skutečně s př́rodou, a potom jsem začala cítit bolest Země a bylo to fakt hrozné, prostě jsem brečela. A potom mě napadlo, že kdyby každý člověk zasadil jeden strom ve svém životě a staral by se o něj [...], potom by tato země byla úplně jiným místem. (Susi, 13. 11. 2010)

Výzva k jednání, jež je orientované na změnu, je zakořeněna v samotném poslání organizace. Identita jedince praktikujícího alternativní spiritualitu se často snoubí s kritikou mainstreamové společnosti (Bloch 1998; Prince 2000) a ta je jedním ze sdílených znaků nových sociálních i náboženských hnutí. Embercombe iniciuje tázání po tom, ,jak žijeme, jak se k sobě chováme, jak fungujeme jako společnost, jaké jsou naše priority?“ (Robert, 17. 12. 2010). Odpovědi na ně mají obvykle kritický ráz a sahají od představy vymytí mozků reklamou u většinové populace (zaznamenané v rozhovorech s Lucy, Robertem, Timem), přes odmítání masové produkce jídla, masového školství, po kritiku ne-humánnosti a bez-duchosti lpění na materiálním zisku.

Zdá se, že v západních společnostech jsme posedlí zábavou a chováním, které nám umožňuje únik. Moje práce má přivést lidi k uvědomění a spojení se sebou samými v kontextu možnosti udělat něco se situací, v níž se nacházíme. Aby neusnuli. Protože tolik věcí, které tak zvaně máme dělat, nás akorát unavuje. At’ už jde o dívání se na televizi, opíjení se, sportování [...]. (Thomas, 27. 11. 2010)

Vnitřní proměna i experimentování s identitou jsou provázeny snahou o odhalování pravidel „dominantně sdílených kritérií kodifikace“ (Melucci 1996). Kritika expanze funkcionálně racionální logiky (Casanova 1994) se explicitně vyjevuje v tematizování reziduálních problémů, jakými jsou devastace životního prostředí či globální nerovnosti. Otevírá se prostor pro globální holistickou představivost, jejímž výrazem byly např́íklad vizualizace Nové Země, lepšího světa, budoucnosti Embercombe, které mně způsobem jejich praktikování připomínaly kolektivní meditace (účastníci zavřeli oči, hluboce dýchali a po půl hodině sdíleli svoje představy). Všichni aktéři si v rámci rozhovorů byli schopni představovat sebe jakožto součást širšího (někdy i kosmického) celku. Součástí symbolického světa Embercombe je také naděje a víra v to, že svět může být jiný, že spiritualita může být šířena do okolního světa a že se může stát globálním modelem. Tato vize expandování se snoubí s utopií (Melucci 
1996), s vírou v to, že duchovní harmonie jednotlivců může vést k harmonizaci celého světa. Cílem aktivit organizace přitom není jen udržitelná komunita, nýbrž udržitelný svět.

Zmíněné hodnoty a vize jsou součástí diskurzu (Herbert 2003), jenž orientuje jedince k hledání naplněného života, které se prolíná se vztahováním se k sociálním problémům. Vedle holistického významového horizontu a kritiky mainstreamu je to motiv krize, jenž utváří nové paradigma a který umocňuje naléhavost, s níž by mělo dojít ke změně. Susi př́mo říká, že „musíme jednat“. Přijetí tohoto světového názoru připomíná konverzi umožňující vidět svět novýma očima.

\section{Závěr}

V tomto textu jsem prezentovala klíčové debaty, teorie a koncepty tematizující roli alternativní spirituality v kontextu působení nových sociálních hnutí. Jejich př́nos jsem vztahovala k možnosti vysvětlit sociální dopad praktikování alternativní spirituality, který byl vymezen jako potenciál ke vztahování se a snaze o řešení problémů sahajících za hranice soukromého života jedince. Rozlišila jsem charakter teorií sekularizačního a transformačního paradigmatu. Revidovala jsem koncept holistického milieu Paula Heelase a Lindy Woodhead (2005) a rozpracovala koncept holistické hnutí. Studovaný případ, organizaci Embercombe, jsem vymezila jako jeden z bodů sít’ové struktury tohoto hnutí. V další analýze zkoumaného problému jsem využila především Casanovovu (1994) teorii deprivatizace zachycující situace, v nichž náboženství vstupuje do veřejné sféry, a Beyerovo (1994, 2001) tematizování tzv. reziduálních problémů jako jedné z hlavních funkcí náboženství v současném světě. Argumentovala jsem pro souběžné studium nových náboženských a nových sociálních hnutí, přičemž při vymezení klíčových charakteristik nových sociálních hnutí jsem se opřela o dílo Alberta Melucciho (1996).

Analýza dat vedla k následujícím zjištěním. Symbolické rámce obsažené v konceptu spirituální cesty orientují jedince $\mathrm{k}$ představě proměny sebe sama skrze kladení si zásadních životních otázek konfrontujících jeho ustavené představy o sobě samém a svém vztahu ke světu. Součástí spirituálního růstu se v perspektivě aktérů stává jednání zaměřené na vnější svět, které se neobejde bez „boje“ za to, co jedinec považuje za správné. V embercombské kultuře je jedinec veden k přijetí vize spravedlivého a udržitelného světa a socializován do aktivní role, kterou má v jejím naplnění sehrávat. Spirituální transformace tak má prohlubovat zplnomocnění ke změně. V Embercombe proto byla patrná spiritualita aktivizující.

Význam změny se odráží jak v permanentním přetváření individuální identity jedince, tak $\mathrm{v}$ pozitivním hodnocení procesu vyjednávání identity kolektivní (například prostřednictvím instituce snílka). Jedinec zakotvený v sítích významů embercombské kultury věří v experimentování a překračování hranic své komfortní zóny jako v nástroj prolomení dominantní kulturou reprodukovaných symbolických kódů a ustavení kódů vlastních. K těm patř́ především bytí ne-mainstreamovým (vytváření alternativ v různých oblastech života - rodičovství, způsob obživy) a holistické ,propojování“ jedince se sebou samým (rozvíjení jeho autenticity), jeho fyzickým i sociálním prostředím. Spiritualita je v embercombském prostoru experimentující a identitotvorná. 
Poslání organizace, kterým je inspirování k angažovanému jednání pro skutečně udržitelný svět, vychází z představy jeho současného neudržitelného stavu. Tematizování reziduálních problémů (ekologická krize, sociální nerovnosti) produkovaných dominantními sociálními systémy (ekonomický, administrativní) je výrazem kritiky rostoucí autonomie těchto systémů a šíření instrumentální racionality napříč společností. Spiritualita, která má charakter životní síly či posvátné energie, zpravidla umožňuje jedincům chápat sebe samé jako součásti širšího celku a vnímat svůj podíl zodpovědnosti za jeho stav. Pocit přináležení k planetárnímu celku je prohlubován snahou o spojování se se Zemí skrze různé spirituální praktiky (např́klad zasazení jedince). Aktéři jsou vedeni k environmentálnímu či New Age aktivismu, prostřednictvím kterého spiritualita naplňuje veřejnou performanci (Beyer). Spiritualita je v kontextu působení organizace Embercombe angažovaná.

\section{Literatura}

AUPERS, Stef a Dick HOUTMAN. Beyond the Spiritual Supermarket. The Social and Public Significance od New Age Spirituality. Journal of Contemporary Religion, 2006, roč. 21, č. 2, s. 201-222, ISSN 13537903.

BARŠA, Pavel a Ondřej CÍSǍ̌. Levice v postrevolučni době: občanská společnost a nová sociálni hnutí v radikálni politické teorii 20. století. Brno: Centrum pro studium demokracie a kultury, 2004. ISBN 8073250330.

BECKFORD, James A. Religion and Advanced Industrial Society. London: Unwin Hyman, 1989. ISBN 0043012280.

BECKFORD, James A. Social Theory and Religion. Cambridge (UK): Cambridge University Press, 2003. ISBN 0521773369.

BESECKE, Kelly. Seeing Invisible Religion: Religion as a Societal Conversation about Transcendent Meaning. Sociological Theory, 2002, roč. 23, č. 2, s. 179-196. ISSN 0735-2751.

BEYER, Peter. Religion and Globalization. London: SAGE, 1994. ISBN 0803989164.

BEYER, Peter. The Global Environment as a Religious Issue: A Sociological Analysis. In HERBERT, David (ed.). Religion and Social Transformations. Aldershot: Ashgate, 2001, s. 262-281. ISBN 0754608174.

BISHOP, Nicholas. Rationalization of body and spirit: Modern postural yoga as example of bureaucratic discipline and scientific management. Annual Meeting of American Sociological Association. 1.-4. 8. 2008, Boston.

BLOCH, Jon P. New spirituality, self, and belonging: How New Agers and Neo-Pagans talk about themselves. Westport (CT): Praeger, 1998. ISBN 0275959570.

BRUCE, Steve. God is dead: Secularization in the West. Malden (MA): Blackwell, 2002. ISBN 0631232753.

BRUCE, Steve a David VOAS. The Spiritual Revolution: Another False Down for the Sacred. In FLANAGAN, Kieran a Peter C. JUPP (eds.). A Sociology of Spirituality. Aldershot: Ashgate, 2007, s. 23-61. ISBN 9780754654582.

CASANOVA, José. Public Religions in the Modern World. Chicago: University of Chicago Press, 1994. ISBN 0226095355.

CORRYWRIGHT, Dominic. Network Spirituality: The Schumacher-Resurgence-Kumar Nexus. Journal of Contemporary Religion, 2004, roč. 19, č. 3, s. 311-327. ISSN 13537903.

EMBERCOMBE. Catalyst [online]. Embercombe, [nedatováno] [cit. 2011]. Dostupné z: http://www. catalystcourse.co.uk/index.php?option=com_content\&view=article \&id=2\&Itemid=4. 
FÁREK, Martin. Hnuti Haré Kršna: institucionalizace alternativního náboženství. Praha: Karolinum, 2008. ISBN 9788024615790.

FORMAN, Robert K. C. Grasroots Spirituality: What It Is, Why It Is Here, Where It Is Going? Charlottesville (VA): Imprint Academic, 2004. ISBN: 0907845681.

HADDEN, Jeffrey K. Toward Desacralizing Secularization Theory. Social Forces, 1987, roč. 65, č. 3, s. 587-611. ISSN 00377732.

HANEGRAAFF, Wouter J. The New Age Movement and the Esoteric Tradition. In VAN DEN BROEK, Roelof a Wouter J. HANEGRAAFF (eds.). Gnosis and Hermeticism. From Antiquity to Modern Times. New York: State University of New York, 1998, s. 359-382. ISBN 079143611X.

HANEGRAAFF, Wouter J. Defining religion in spite of history. In PLATVOET, Jan G. a Arie L. MOLENDIJK (eds.). The Pragmatics of Defining Religion. Contexts, Concepts and Contests. Leiden: Brill, 1999, s. 337-379. ISSN 0169-8834.

HANEGRAAFF, Wouter J. Spectral Evidence of New Age Religion: On the Substance of Ghosts and the Use of Concepts. Journal of Alternative Spiritualities and New Age Studies, 2005, roč. 1, č. 1, s. 35-58. ISBN 978-1-4196-0359-0.

HANNIGAN, John A. Social Movement Theory and Sociology of Religion: Toward a New Synthesis. Sociological Analysis, 1991, roč. 52, č. 4, s. 311-331. ISSN 00380210.

HEELAS, Paul. The New Age Movement: The Celebration of the Self an the Sacralization of Modernity. Oxford: Blackwell, 1996. ISBN 0631193324.

HEELAS, Paul. The Infirmity Debate: On the Viability of New Age Spiritualities of Life. Journal of Contemporary Religion, 2006, roč. 21, č. 2, s. 223-240. ISSN 13537903.

HEELAS, Paul. The Holistic Milieu and Spirituality: Reflections on Bruce and Voas. In FLANAGAN, Kieran a Peter C. JUPP (eds.). A Sociology of Spirituality. Aldershot (UK): Ashgate, 2007, s. 63-79. ISBN 9780754654582.

HEELAS, Paul. Spiritualities of Life: New Age Romanticism and Consumptive Capitalism. Malden: Blackwell, 2008. ISBN 9781405139380.

HEELAS, Paul a Linda WOODHEAD. The Spiritual Revolution. Why Religion is Giving Way to Spirituality. Malden: Blackwell, 2005. ISBN 1405119586.

HERBERT, David. Religion and Civil Society: Rethinking Public Religion in the Contemporary World. Aldershot: Ashgate, 2003. ISBN 0754613399.

HERVIEU-LÉGER, Daniéle. The transmission and formation of socioreligious identities in modernity. International Sociology, 1998, roč. 13, č. 2, s. 213-228. ISSN 02685809.

HETHERINGTON, Kevin. Expressions of Identity. Space, Performance, Politics. London: SAGE, 1998. ISBN 0803978766.

HUNT, Stephen J. Alternative Religion: A Sociological Introduction. Aldershot: Ashgate, 2003. ISBN 0754634108 .

KNOBLAUCH, Hubert. Spirituality and Popular Religion in Europe. Social Compass, 2008, roč. 55, č. 2, s. 140-153. ISSN 00377686.

LANCASTER UNIVERSITY. The Kendal Project [online]. Department of Religious Studies, Lancaster University, 2003 [cit. 2011]. Dostupné z: http://www.lancs.ac.uk/fss/projects/ieppp/kendal/outputs. htm

LASCH, Christopher. The Culture of Narcissism. The American Life in an Age of Diminishing Expectations. New York: Warner Books, 1979. ISBN 0446932647.

LICHTERMAN, Paul. The search for political community: American activists reinventing commitment. Cambridge: Cambridge University Press, 1996. ISBN 0521483433.

LIPOVETSKY, Gilles. Éra prázdnoty. Úvahy o současném individualismu. Praha: Prostor, 2008. ISBN 9788072601905. 
LUCKMANN, Thomas. Invisible Religion. The Problem of Religion in Modern Society. New York: The Macmillan Company, 1967. ISBN 0025767003.

LUCKMANN, Thomas. Shrinking Transcendence, Expanding Religion? Sociological Analysis, 1990, roč. 51, č. 2, s. 127-138. ISSN 0038-0210.

LUŽNÝ, Dušan. Nová náboženská hnutí. Brno: Masarykova univerzita, 1997. ISBN 8021016450.

LYNCH, Gordon. The New Spirituality: An Introduction to Progressive Belief in the Twenty-first Century. London: I.B. Tauris, 2007. ISBN 9781845114145.

McGUIRE, Meredith B. Religion: The Social Context. 5th ed. Belmont (CA): Wadsworth, 2002. ISBN 0534541267.

McGUIRE, Meredith B. Lived Religion: Faith and Practice in Everyday Life. Oxford: Oxford University Press, 2008. ISBN 9780195172621.

MELUCCI, Alberto. The Symbolic Challenge of Contemporary Movements. Social Research, 1985, roč. 52, č. 4, s. 789-816. ISSN 0037783X.

MELUCCI, Alberto. Challenging codes: Collective action in the information age. Cambridge: Cambridge University Press, 1996. ISBN 0521570514.

ONDRAŠINOVÁ, Michaela. Jak uchopit „neuchopitelné“? Diskuze o detradicionalizované religiozitě. In LUŽNÝ, Dušan a David VÁCLAVÍK (eds.). Individualizace náboženství a identita. Poznámky k současné sociologii náboženství. Praha: Malvern, 2010, s. 118-142. ISBN 9788086702698.

PARTRIDGE, Christopher. The Re-enchantment of the West. Volume 1, Alternative Spiritualities, Sacralization, Popular Culture and Occulture. London: T\&T Clark International, 2004. ISBN 567041336.

STAKE, Robert E. Multiple Case Study Analysis. New York: The Guilford Press, 2006. ISBN 1593852487.

TSCHANNEN, Olivier. The Secularization Paradigm: A Systematization. Journal for the Scientific Study of Religion, 1991, roč. 30, č. 4, s. 395-415. ISSN 00218294.

WILLAIME, Jean-Paul. Religion, individualization of meaning, and the social bond. In LAERMANS, Rudi, Bryan R. WILSON a Jaak BILLIET (eds.). Secularization and Social Integration. Papres in Honour of Karel Dobbelaere. Leuven: Leuven University Press, 1998, s. 261-275. ISBN: 9789061869320.

YORK, Michael. The Emerging Network. A Sociology of New Age and Neo-pagan Movements. Lanham: Rowman \& Littlefield, 1995. ISBN 0847680010.

\section{Autorka}

Jana Obrovská působí jako doktorandka na Katedře sociologie Masarykovy univerzity v Brně. K oblastem jejího zájmu patří sociologie vzdělávání a sociologie kultury.

Kontakt: obr@mail.muni.cz 